\title{
Artelogie
}

Recherche sur les arts, le patrimoine et la littérature de l'Amérique latine

\section{Online photography beyond the selfie: The "shareware body" as tactical media in works by Érika Ordosgoitti}

Lisa Blackmore

\section{(2) OpenEdition}

Electronic version

URL: https://journals.openedition.org/artelogie/1407

DOI: 10.4000/artelogie. 1407

ISSN: 2115-6395

\section{Publisher}

Association ESCAL

\section{Electronic reference}

Lisa Blackmore, "Online photography beyond the selfie: The "shareware body" as tactical media in works by Érika Ordosgoitti", Artelogie [Online], 7 | 2015, Online since 15 April 2015, connection on 11 April 2022. URL: http://journals.openedition.org/artelogie/1407 ; DOI: https://doi.org/10.4000/ artelogie. 1407

This text was automatically generated on 11 April 2022.

Association ESCAL 


\title{
Online photography beyond the selfie: The "shareware body" as tactical media in works by Érika Ordosgoitti
}

\author{
Lisa Blackmore
}

I would like to thank Érika for her kind and invaluable collaboration in this research and for her generous access to her archive materials that were of immense help. Her video work and documentation of performances is available on her YouTube channel "Érika Ordosgoitti"; her blog, soloestoysiendo.blogspot.com, features Ordosgoitti's own reflections on her practice and her Facebook profile is Érika Ordos. She is represented in Caracas by Oficina \#1 (http:// www.oficina1.com).

1 For the past five years Venezuelan artist Érika Ordosgoitti (Caracas, 1980) has used Facebook, along with other social media networks, to circulate her work beyond the sites where contemporary art is conventionally exhibited and viewed. Ordosgoitti's diverse practice is centred on intimate actions that present her body to public scrutiny, whether by foregrounding her biological cycles or appearing unclothed in public spaces or in video or photographic works. In her impromptu acts, Ordosgoitti might appear naked astride iconic sculptures in Caracas, walking along the fetid banks of the River Guaire or interrupting the pedestrian transit on a steep stairway of a barrio. It is the documentation and online publication and debate around photographs of these and other actions that will be the focus of this article.

In her artist statement, entitled "Declaración de la independencia", Ordosgoitti elucidates her online presence intentions by explaining that do so because she wants "otras personas tenga acceso a mis imágenes" (other people to have access to my images) (ORDOSGOITTI: 2011, July 29). While at first glance this decision appears motivated by democratizing intent, whereby greater visibility would ensure a wider audience, this article contends that Ordosgoitti's quest for broader engagement strategy also entails more complex and critical implications in moving beyond the 
museum and the marketplace. As such, the examination of her tactical use of online photographs aims to reveal that by publishing her work online Ordosgoitti expands the conventional temporality of performance. She protracts the culminated action not only through photographic capture, but by publishing these images online, forcing the preterite temporality of these two aesthetic forms into the present continuous of online exchanges between users.

3 Secondly, the analysis aims to reveal how her foregrounding of nudity stimulates polemic and censorship entails a critical embrace and redeployment of "circulationism" -that is, "public relations of images across social networks, about advertisement and alienation" (STEYERL: 2013). The artist's nude body, as the central trope in her practice, counters the dominant depictions of self-representation in online photograph. While Ordosgoitti's images are always of herself, they are neither part of the complacent "selfie culture" of mainstream social networking, nor do they respond to self-reflexive performances that scholars have identified in amateur, vernacular selfportraiture (ARDÉVOL \& GÓMEZ-CRUZ: 2012).

Screen capture of an image and comments from Ordosgoitti's Facebook profile

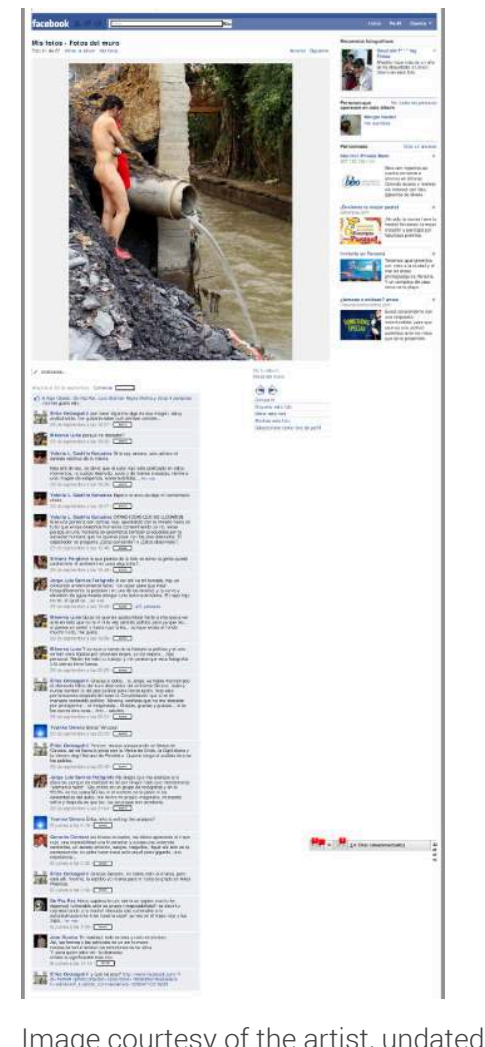

In this regard, the ultimate aim of this analysis is to contend that the release of Ordosgoitti's body as "shareware" among users detonates a series of processes that reveal the ambivalence of global digital platforms. On one hand, online interaction buttresses the collaborative co-authorship that her practice actively pursues, enabling polysemous, contested interpretations to appear over time in the para-photographic frame. Yet, on the other, the persistent censorship and deactivation of her account bring to light the invisible disciplinary controls underpinned by entrenched social convention, the post-Fordist economy where personal information is rationalized as 
exchange value, and punitive controls implemented through the panopticism of Facebook's virtual architecture.

5 However, given that Ordosgoitti's work has received scarce attention beyond Venezuela and her international exposure is only recently growing with the grant she was awarded by the Fundación Misol, Colombia, in October 2014, the some preliminary notes regarding her place in digital culture studies, Latin Amercian art and the development of her work will help to contextualize her practice before the above theses are qualified with a close analysis of her practice. ${ }^{1}$

\section{Context}

Ordosgoitti's practice garners relevance not only due to the growth of Internet penetration and social media across the social spectrum in Venezuela, as will be shown below, but also in the context of expanding interest of digital culture scholarship as a point of dialogue with existing cultural traditions and practices. As Claire Taylor and Thea Pitman contend, while online practitioners cultivate "the emergence of new genres and cultural forms", their work also retains continuities "with older, predigital formats and the discourses they were instrumental in circulating" (TAYLOR \& PITMAN, 2013: p.5). In this sense, Ordosgoitti's work speaks to traditional practices of performance and photography, while also raising questions about what happens when those forms go online. In this sense, analysing her practice entails an engagement of what Hal Foster has termed the "changed status of the 'work' of art in the age of information" (FOSTER: 2007, p.74), but also an acknowledgement of pre-digital backgrounds.

7 Beyond issues of the way digital technologies affect existing aesthetic forms, much digital cultural production has engages standing thematic concerns due to the way that online practice works through offline topics, thus revealing the porosity of online/ offline borderlines. Sited issues such as territory, history, politics, identity, and the body, which have long featured as inquiries in Latin American art, thus endure and are negotiated in the local and global context of emergent digital technologies and practices. By this token, it is evident that the Internet is not a brave new world of total transformation, but a site of mediation with persistent tensions. This, Claire Taylor insists in a recent study, entails fruitful, tactical negotiations of offline and online issues that are germane to historical and contemporary conflicts. In this framework, when digital media deals with contentious topics such as borders and immigration, it elucidates "how these borders shift, persist and are reworked online" (TAYLOR, 2011: p. 304). Digital cultural practice, in this sense, enters a new realm of circulation taking its historical baggage with it.

8 The predominance of dystopian and monumental urban settings in photographs of performances that Ordosgoitti subsequently posts online reveals similar overlaps in offline-online topoi, drawing viewers' attention to the urban landscape in which her naked body stands out and eliciting comments that question the significance of those settings in relation to the spectrum of personal, political, affective and artistic references that each person brings to bear on the image. In ContraCorriente Caroata Caroata (shown below), for instance, Ordosgoitti's action involves her walking alongside the banks of the River Guaire in Caracas, which runs through the capital's valley. The counterpoint that her naked body strikes with the hostile surroundings helps to bring 
to light the river's literal and symbolic import. The vulnerability connoted by Ordosgoitti's nudity is evocative of the currents of urban violence that run literally through the river, in which dead bodies regularly emerge. In addition, her intervention connects inter-textually with a collective imaginary. While the river featured in late nineteenth century and early twentieth century pastoral landscapes, the burst of urban growth in the capital after the general national transfiguration engendered by the discovery of oil in 1922 can be traced through the channeling of the river in the 1950s and its current state of contamination. In this sense, the enduring promise of project of the "Saneamiento del Río Guaire" (Sanitation of the River Guaire undertaken by the government of late president Hugo Chávez and still underway with funding awarded in 2012 by the Inter-American Bank) is evoked in visual terms. Indeed, the symbolic association of the river with social wellbeing also featured as a motif in the photographic series Guaire (2008-9) developed by Venezuelan photographer Amada Granado around the same time as Ordosgoitti's action.

Left: ContraCorriente Caroata Caroata, Caño Amarillo, undated. Right: Venus de la Policía de Caracas, 2011 Photo: Nancy Urosa.
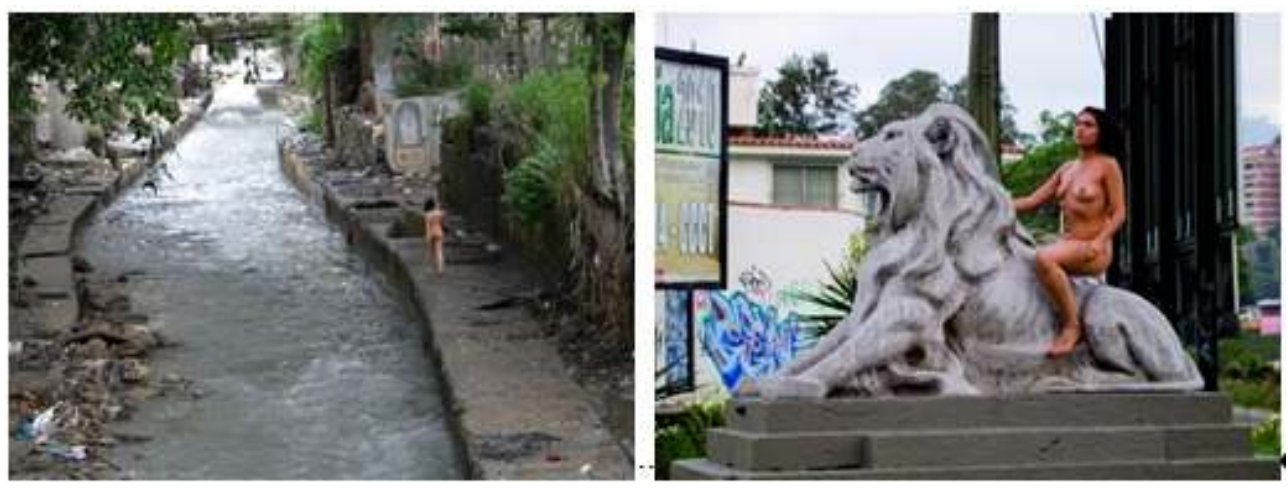

Left: Rutmary Colmenares Siu. Right: Images courtesy of the artist.

9 To return to broader contextual coordinates, Ordosgoitti's work dialogues with a tradition Latin American of female artists who use their bodies to critical ends. The common strategy running through the work of the diverse practitioners that Diana Taylor and Roselyn Constantino analyse is that they "recuperate and recirculate the visual, linguistic, symbolic, and more recently, technological codes that circumscribe identities and modalities of seeing, representing, and knowing. In different ways, their performative styles simultaneously interrogate the politics of representation and the strategies of power written across the female body, which serves as both the message and the vessel" (TAYLOR \& CONSTANTINO, 2003, p.22). A similar conclusion might be drawn about Ordosgoitti's work, particularly given her insistence, through performance, on using her body as her main material in order to recuperate a corporeal modality of representing and signifying, while its construction as a public, rather than private, body looks outward to the social and technological normalizing codes that work to discipline the female corpus.

10 Finally, generational, thematic and aesthetic connections can be drawn between Ordosgoitti and other emergent to mid-career female artists who also interrogate or deploy the body to critical ends. In this context, Ordosgoitti's performatic presentation of her body's vital fluids in video works, such as the series Micción to be mentioned below, dialogues with the "grotesque, abject and 'excessive' female body" that Lavery 
and Bowskill identify as the central critical thrust of the practice of Guatemalan Regina José Galindo (LAVERY \& BOWSKILL, 2012, p.56). That is, in works like Cicatrices en la cabeza (2013) and Hilo de tiempo (2012) Ordosgoitti and Galindo, respectively, expose the margins of their bodies through the trope of mortality, thus evoking the rampant violence that plagues both Venezuela and Mexico. ${ }^{2}$ With regards to the nexus of the female body and the interface of offline social mores that become equally visible on digital cultural platforms, Ordosgoitti's emphasis on the taboo of female nudity in social media could be read productively alongside Peruvian artist Daniela Ortiz's critical interrogation of class-based concealments of subaltern women. In the photographic series 97 empleadas domésticas (2010) Ortiz presents images "meticulously sourced from Facebook [that] reveal racialized class divisions between maids with indigenous and mestizo features and the primarily Caucasian households their serve" (MERGEL ET AL, 2013: p.106). Ordosgoitti's re-presentation of her censored body and Ortiz's accumulation of the truncated bodies of maids clearly signal a tactical negotiation of offline prejudices by interrogating their enduring presence online.

Multiple notification of contravenence of Facebook Community Guidelines reposted by Ordosgoitti on her Facebook profile, circa 2011.

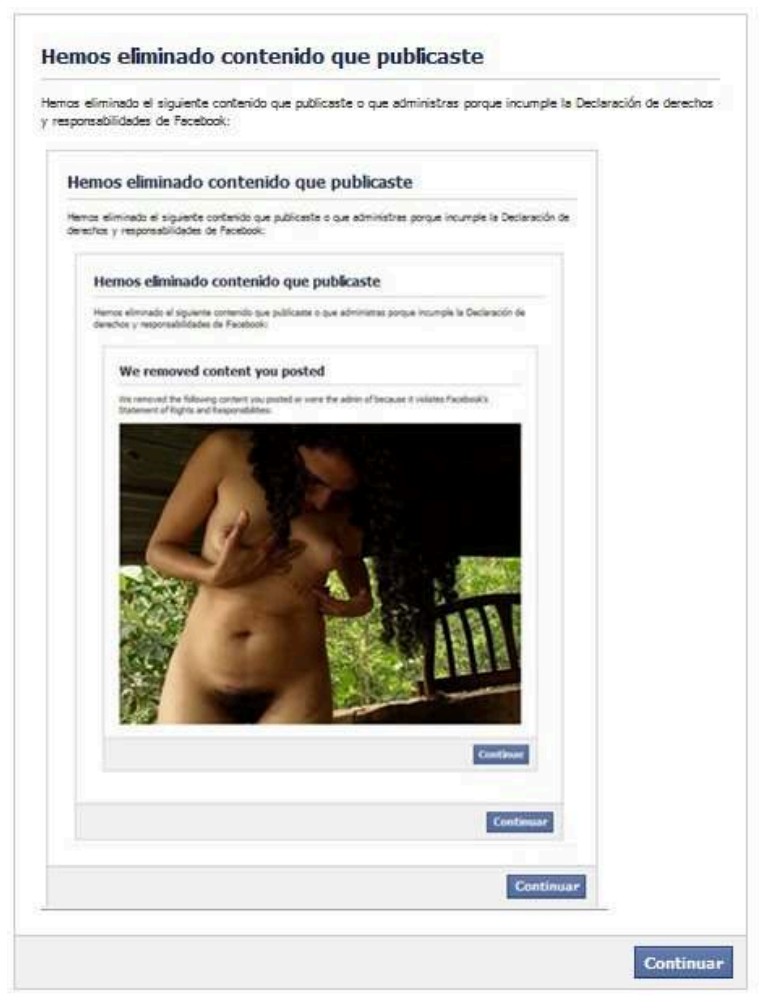

Screen shot courtesy of the artist, undated.

\section{From campus to Facebook}

11 As an emergent artist who is now beginning receiving attention outside Venezuela, Ordosgoitti's early works were mainly visible to her fellow students and professors at the Universidad Nacional Experimental de las Artes (UNEARTE) campus in Caño Amarillo, Caracas, where she studied her BA in Fine Art. The performance and video 
works from this period (2008-9) are characterized by a precarious style of documentation that is off-centred and low-fi, whereby the camera is an accessory on the fringes of the work that enabled its capture and later revision. Thematically, Ordosgoitti's practice at this time centred on intimate bodily cycles and fluids, usually urine or menstrual blood that are taboo in the public domain. In this regard, the artist explored her body's contact with spaces and/or actions that involved risks and in which the body and its cycles were pushed to the limits of safety and decency in various ways. One group of works from this period involved spontaneous performances where the artist free climbed the art school buildings, while another, grouped under the common heading Micción, mentioned above, explored the act of urinating in front of a viewing public. The performance Decente (2008) epitomizes these early works' emphasis on transgressing public/private boundaries and signalling the body's biological cycles; in it the artist urinated fully clothed into a series of champagne flutes before toasting with a friend and drinking the glass. In short, the action inverted a taboo bodily fluid to transform a private and usually invisible act into a premise for a public celebration of corporeal processes.

Since these beginnings, Ordosgoitti has developed several parallel modalities of performance in which photographic documentation has gained an increasingly central role. For clarity, these modalities require a brief typology. The first involves unannounced actions where Ordosgoitti appears nude in diverse urban settings, ranging from public monuments and squares to informal spaces, such as abandoned buildings or ruinous infrastructure. ${ }^{3}$ Despite their impromptu nature, these happenings also entail planned photographic documentation carried out by different collaborators with varying degrees of expertise. In turn, the artist has created her own taxonomy for these works, which she classifies as fotoperformances or fotoasaltos. The categories signal the intentional incorporation of photography as a central part of the work so that the performance is (also) for the camera. Thus, the fotoperformance photography serves the conventional purpose of documenting the performance while surpassing it through the artist's tactical engagement with the camera. In turn, this premeditated, rather than circumstantial dialogue between offline space, body, performance, photography and online sites produces a constellatory field of concerns and traditions that come to bear on the works to be analysed in depth after these introductory notes.

Secondly, alongside her fotoasaltos, Ordosgoitti develops performances specifically for video, which she classifies as autovideos. These have included works such as Corra (2013) and Me abro la cabeza (2013), where a naked Ordosgoitti engages the camera head on, reciting self-penned poems whose register shifts continually from the philosophic to the prosaic, in continuous single shots where Caracas' motorways or barrios provide the backdrop to the action, as can be seen on her YouTube channel. A third type of performance involves pre-planned participations in public and private festivals or art institutions and often feature violence as a recurrent theme, evoked through recitals of the artist's self-penned poems and other actions that unfold in situ. 
Cicatrices en la cabeza, performance, 2013.

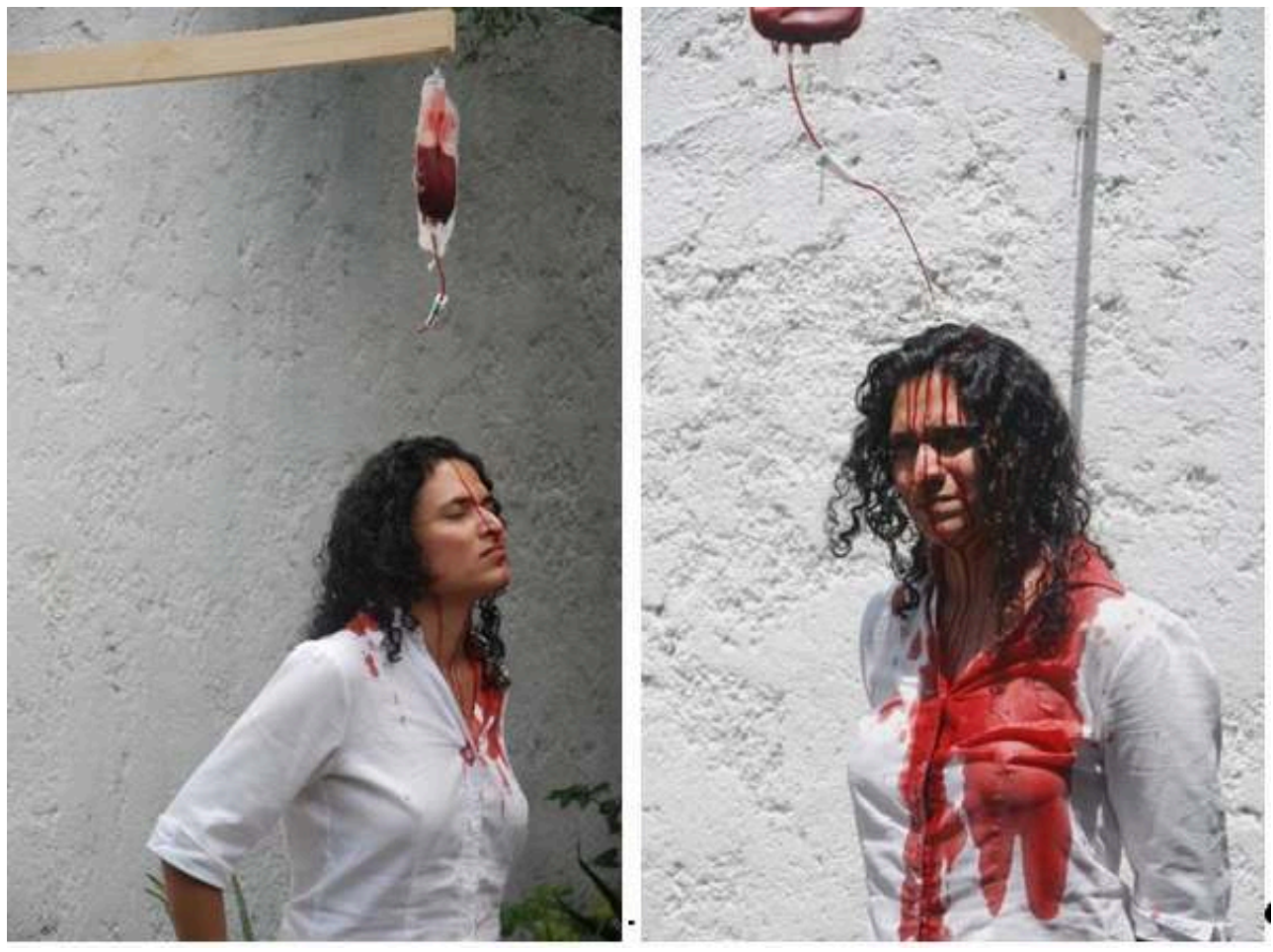

Galería GBG, Caracas. Retrieved from artist's Facebook profile.

Photos: anonymous.

Unlike her more impromptu performances, this type of action is not a spontaneous act that interrupts an unwitting passersby going about their business, but a staged event for a specific voluntary audience. One recent example of such works was the 15-minute performance entitled Cicatrices en la cabeza (2013), presented at the commercial art gallery GBG Arts in a residential area of Caracas during the exhibition Ética - Estética Política, curated by María Elena Ramos. The action consisted in the artist standing under a medical drip bag of her own blood, which seeped onto her pristine white shirt as she recited a poem whose confrontational tone called for an acknowledgment of the inescapable fate of mortality and bodily decomposition. Remember, she told the public, "que todo destino es putrefacto alimento de moscas (...) reconcíliense con la podredumbre" (that all destinies are rotting food for flies (...) reconcile yourselves with putrefaction). Cicatrices en la cabeza is a relevant counterpoint to Ordosgoitti's use of social media that will be explored below because this type of performance is premeditated for an audience that is primed and physically present and its enactment in a private gallery away from urban thoroughfares necessarily means that it reaches only the audience already invested in seeing the work. Therefore, it is useful to bear in mind this more conventional, albeit emotive and forceful, mode of performance in the analysis to follow for it will serve as a contrast to evince the very distinct strategies at work when Ordosgoitti uses social media to expand the circulation and temporality of her performances.

Tactical manoeuvres: offline performance and online photographs

The very fact that the majority of Ordosgoitti's actions have been documented through photography or video is what makes it possible to discuss her works. This 
documentation has, in turn, been republished on social media, whether on the artist's blog, her Facebook profile, her YouTube channel, or a mixture of them all. Consequently, this ease of access to her work suggests that the artist is highly aware of the scope of her live actions, both in terms of the public they engage and their ephemeral nature. In this light, web presence emerges as a prevalent strategy in Ordosgoitti's practice, which responds to the intention cited above, namely to reach otra gente: other people beyond loyal publics already engaged in the art scene or passersby who happen fortuitously upon her appearances in urban spaces.

In this regard, two tactical gestures can be identified in Ordosgoitti's online activity, the first of which is spatial in nature. That is to say, Ordosgoitti's pursuit of online interactivity bypasses the restricted reception of offline exhibitions spaces found on the conventional art circuit, which in Venezuela draws a reduced audience. While there are no official statistics that reveal footfall in art institutions, it is relevant that the private gallery where her work has most frequently been shown -Oficina No.1- is situated in an art centre that, although open to the public in general and free of cost, is protected by high walls, security guards and with a lack of evident signage to identify it. The result of these architectural characteristics is that passers-by rarely happen upon the space unless they already know about it.

of course, the gesture towards expanded fields for the circulation and practice of contemporary art does not only interpellate the potential limitations of physical spaces, which, incidentally, Ordosgoitti in no way shuns in her work, as her extensive participation in group and solo exhbitions confirms. That said, her online works do pursue circulation and interaction in non-specialist, online "sites" that are usually the preserve of everyday social networking and exchange, rather than settings where the specialised codes and reception of the modern "fields" of aesthetic production are a common feature.

19 In this regard, this tactic engages the mixture of specialist tangible site (museum, gallery) and intangible cultural capital (habitus) that Bourdieu identified as in the terrain of art production and reception. ${ }^{4}$ In The Rules of Art the "art field" is classified by the production of art for its own sake, rather than for a specific social (or religious) use: it is considered a symoblic and physical space distanced from concerns and habits of daily life. While this field is grounded in the complicity of institution artist and audience and the social capital and habitus that appear to confer autonomy on this network of relations, one could argue that the social network of Facebook provides in principle a "site" where, access to internet notwithstanding, the habitus is nonspecialised (BOURDIEU, 1996). In this regard, by taking her performance online beyond the conventions of the "white cube" has the potential to widen its circulation. This, indeed, is presaged by the press coverage of Ordosgoitti's interruptions of public spaces. While the actual performances are ephemeral affairs, the reactions that have appeared repeatedly across online media in Venezuela under headlines such as "Esta mujer se desnudó sobre la estatua de Simón Bolívar en Barquisimeto" (This woman took her clothes on the statue of Simon Bolivar in Barquisimeto), shown below, signal resonances that emerge beyond the specialist pages dedicated to art and culture from the mainstream of conventional news topics (LAGRANCIUDAD, 2013). 
Left: Screen shot of an article on Ordosgoitti's performance in Barquisimeto, Venezuela, April 2012 ; Right: Example of web results regarding the intervention.

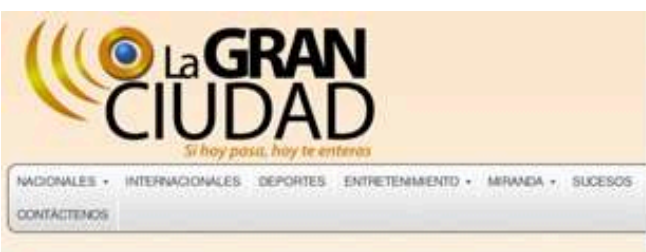

La Foto: Esta mujer se desnudó sobre la estatua de Simón Bolívar en Barquisimeto

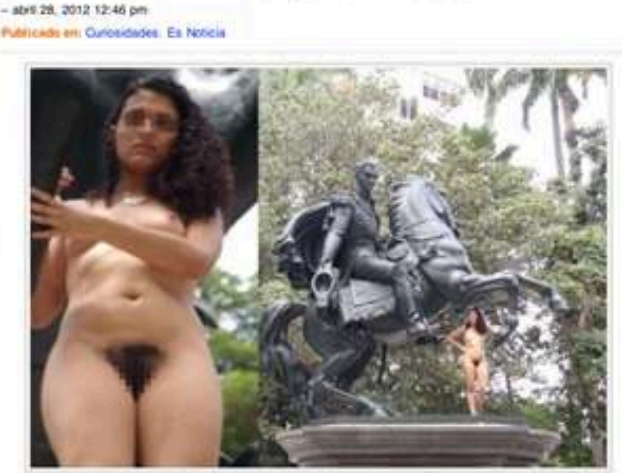

Escandalo: Una mujer se desnudó sobre la estatua de zuliaprensa biogspotcomb. Jescandalo-una-mujer-se-d. - Transiase this page

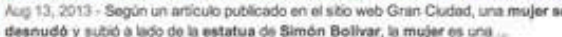

La Foto: Esta mujer se desnudó sobre la estatua de Simón

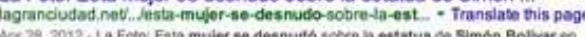

Mujer se desnuda sobre la estatua de Simón Bolivar en .

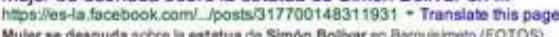

La mujer que se desnudó en la estatua de Simón Bolivar en..

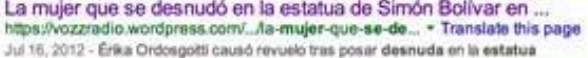
ecuestre de simon Bolivar en Barquiminoto. Pues b ha vueto a hace.

Mujer se desnudó sobre la estatua de Simón Bolivar en onteraterd com/. imujer-so-desnudo-sobre-la-estatua-d.-Translate gis page

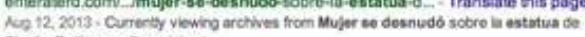
Sinde Botvar en Barquiemeso.

Asombro cuando mujer desnuda posó en estatua de Simón . Www informeonline com/. Aotes-asombro-cuando-m.. - Translate this page

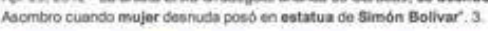

Morocho... on Twitter. Mujer se desnuda sobre la estatua de ..

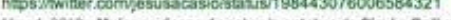
Mar 4, 2012- Mujor se descuda scobe la estatua de Sindon Bollvar en.

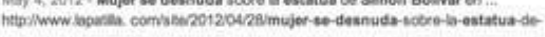

Migue on Twitter: "Mujer se desnuda sobre la estatua de ...

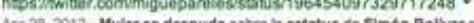

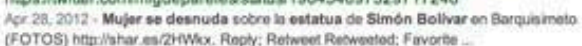
between Ordosgoitti's multi-faceted practice and the shifting realms and composite strands of visual culture. Against specialised discussions of aesthetic traditions from art history or aesthetics, the visual cultural turn has entailed a socially engaged theory of visuality that interrogates existing hierarchies of high or mass culture, displacing the exceptional focus of art history to consider imaging, viewing, the context in which this happens and the power relations these activities entail (MITCHELL, 2002). Thus, just as Mieke Bal proposes that visual culture is a heterogeneous field that does not occupy a specific site (nor, indeed, a body of scholars who consistently agree on what it is) but shifts between different disciplines (BAL, 2003, pp.1-32), this indeterminacy also helps to elucidate Ordosgoitti's practice: by beginning with performance, coining the neologistic fotoperformance, and then distributing her work online for comment, she moves within multiple fields of visuality engaging their attendant conventions on her way.

The second tactical gesture that comes to light is temporal. Indeed, in her statement of intent the - "Declaración de la independencia" mentioned above- Ordosgoitti alludes tacitly to the recurrent dilemma that faces performance. For its ephemeral, embodied unravelling (whether spontaneous or premeditated) action to endure beyond the finite sensory experience of the happening, it is often documented photographically. As a result, three-dimensional, haptic, and time-based corporeal experience is harnessed as a bi-dimensional freeze-framed representation. To gloss Susan Sontag, such images summarise performance into digestible but ultimately unrealistic representations that are "not about significant details, illuminated with a flash, fixed forever. Photographs are" (SONTAG: 1979, p.81). Following the classic axiom that photography captures an instant from the present to embalm it in the preterite tense, Ordosgoitti thus acknowledges photographic representation as a necessary means to an end - a vessel 
that facilitates the engagement that will emerge after the finite performance has finished.

Indeed, the artist's archive reflects this concern through her identification of images as para difusión a través de internet (for internet publication), which signal the inception of a tactical intentionality whereby photography will secure her offline actions a latter iteration online. "Aunque adverso la representación", she states, "mis imágenes fotográficas no escapan de ella. Son representaciones y trabajan con representaciones. Son representaciones de actos libres. (...) Hay un instante de libertad plena. Ése es el evento del arte, la performance. Ese microsegundo y luego las consecuencias que la delicada realidad erupciona" (Although I am against representation, my photographs do not escape from it. They are representations that work with representations. They are representations of free acts. (...) There is an instant of complete freedom. That is the event of art, performance. That microsecond before the consequences that the delicate reality brings forth) (ORDOSGOITTI, 2011, July 29). In this sense, the finite instant of freedom enacted through performance is a microsecond that detonates realtime consequences: as long as her images are online and are viewed, they have the capacity to catalyse plural comments and interpretations. In short, performance and exhibition are converted into protracted happenings where the post-performatic reality emerges as a potentially continuous temporality.

Screen shot of Ordosgoitti's profile with comments.

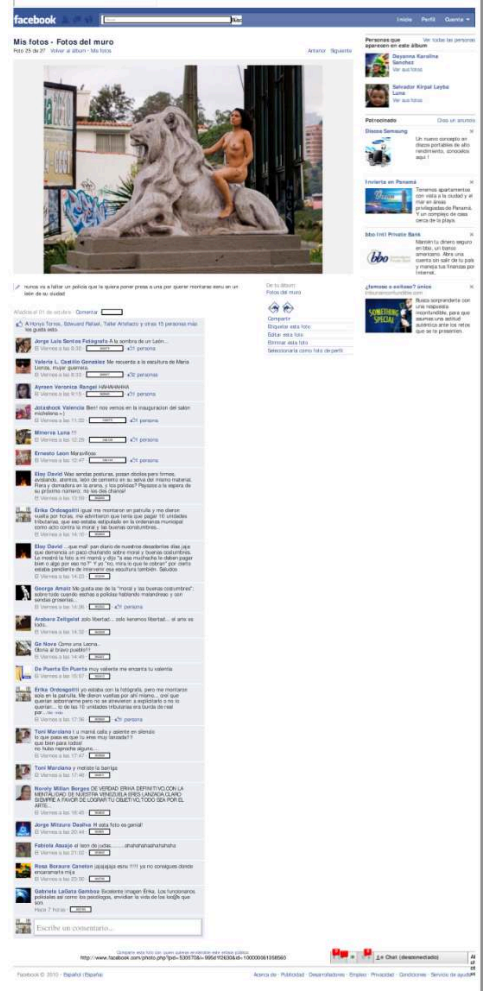

Image courtesy of the artist, undated. 


\section{The makings of collaborative authorship: shareware body, circulationism, and censorship}

Ordosgoitti's choice of Facebook as a platform for expanding art practice is not without significance in Venezuela. Of the nation's population of approximately 28 million, at the end of 2012 there were nearly 10 million Facebook accounts registered there with a penetration of 34\% (INTERNETWORLDSTATS, undated). Indeed, by January 2014, the Venezuelan government considered platforms like Facebook and Twitter to be so crucial to affecting political opinions and events that it created a Vice Ministry for Social Networks, although its operative functions are as yet unclear (SCHWARFENBERG, 2014). What is more, the global ubiquity of Facebook, confirmed in 2012 when scholars estimated together its users would make up the third largest country in the world with over 955 million citizens, also suggests that it is factor to consider in contemporary discussions of digital experience, but also of legislative, political, and economic factors, as well as the affective relations and behavioural tendencies that it engenders, normalizes or castigates (LEE, 2013: p.xiii).

In the context at hand, though, once Ordosgoitti has posted photographs of her performances on Facebook they exposed to a "'promiscuity of collaborations"', where personal and/or virtual "friends" take part in the evolving post-production of the work (FOSTER, 2007: p.74). Of course, the continual evolution of works of art over time is a familiar concept that precedes the digital age. To be sure, Roland Barthes' declaration of the "death of the author" is just one theoretical proposition of collaborative and polysemous significations predicated on the post-structuralist notion of readerresponse, where "a text's unity lies not in its origin but in its destination" (BARTHES, 1977: p.148). The point is, however, that digital culture intensifies this polysemy by making the post-performatic, para-photographic production of meaning part of an ongoing performance of the work in its expanded afterlife online.

Online, the work is constantly reframed inasmuch as it attracts comments, likes or complaints. The para-photographic frame thus incorporates a range of co-existing interpretations -from the inquisitive and the dismissive, to the analytical, abusive, or celebratory. Indeed, this practice can be considered a particular modality of online performance that echoes the critical intent advocated by Critical Art Ensemble. By combining the offline and online, Ordosgoitti's protracted performance "oscillate[s] between virtual life and everyday life" as it expands into a regular cycle of posting, reading commenting, being censored and reposting images again (CRITICAL ART ENSEMBLE, 1994, p.64). This practice thus emerges as the work's modus operandi: a developing performance that takes the gerund form of a non-finite verbal noun. Rather than one performatic action, the developing performance online involves a concatenation of collaborative acts that enhance the debates around her work through an interactive cyclical process of exchange, censorship and re-publication, exchange, and so on.

Significantly, though, this process is perhaps only successful due to the combination of Ordosgoitti's central tropes: the nude body and monumental or dystopic sites that are familiar to Venezuelans, which engage the local and global simultaneously. First, the location of Ordosgoitti's body in liminal no-places or commemorative national sites in Venezuela creates a "particular visuality or visual quality that addresses the social constituencies interacting with them" (BAL, 2003: p.11). Her images interpellate 
viewers on the basis of their shared, offline and online identity as Venezuelans who cohabit this territory as an "imagined community", to use Benedict Anderson's term, or who feel a connection to it through some personal, territorial experience (ANDERSON, 1983). Indeed, as the press coverage above showed, her repeated selection of public statues that depict one of the forefathers of Latin American independence, Simón Bolívar, resonates with a broader public that may not be interested in art per se. In this regard, the 2010 exhumation of Bolívar's body and construction of a brand new mausoleum in Caracas are but two examples of the enduring presence of this national forebear in the collective imaginary whose nationalist resonance and heritage value comes into play with Ordosgoitti's actions.

While this interpellation of identity through space is worthy of further analysis, it is the consistent trope of the nude body that, for this article, sheds light on Ordosgoitti's tactical use of photographic representation and digital media. Her insistent posting of photographs of her naked body -in awareness that it contravenes the social network's "Community Standards"- confirms that it is a linchpin in her work's critical gesture. Indeed, this recurrent use of a taboo trope actively stimulates contentions that engage the scale-free criteria of Facebook. Put simply, "scale-free criteria", which Albert-Lásló Barabási has identified as a central mechanism of social media, means that the more clicks, links or comments a publication receives, the more visible it becomes. To use Vito Campanelli's more succinct terms; popular content means the "rich get richer" (CAMPANELLI, 2010: p.76).

Indeed, it is important to note that Ordosgoitti is -ostensibly- a user like any other: she has a profile picture, a cover photo, a timeline and friends (although it should be noted that she no longer automatically adds people via friend requests but sends them a message first to make them aware her work might offend delicate sensibilities). What is more, unlike glitch artists or hackers who alter the corporate design, Ordosgoitti operates within the conventional Facebook interface since it is precisely the existence of invisible instruments of vigilance and control that underpin her disturbance. It is no secret that the "Facebook Community Standards" take a firm stance against female nudity. In their taxonomy of prohibited content, nudity and what the corporation considers "explicitly sexual content" are almost impossible to separate because their broad definition of "content of personal importance" means that representations of the naked body rendered in sculpture, drawing or painting are acceptable as long as they look like art (FACEBOOK, 2013). Thus, whether sexually charged or not, realistic depictions of nudity provide grounds for corporeal censorship. To cite just one example of this grey area, in 2011 Facebook reportedly eliminated a drawing of a topless woman posted by the New York Academy of Art on the grounds that it contained realistic depictions of nipples, which are a Facebook taboo (CHEN, 2011). 


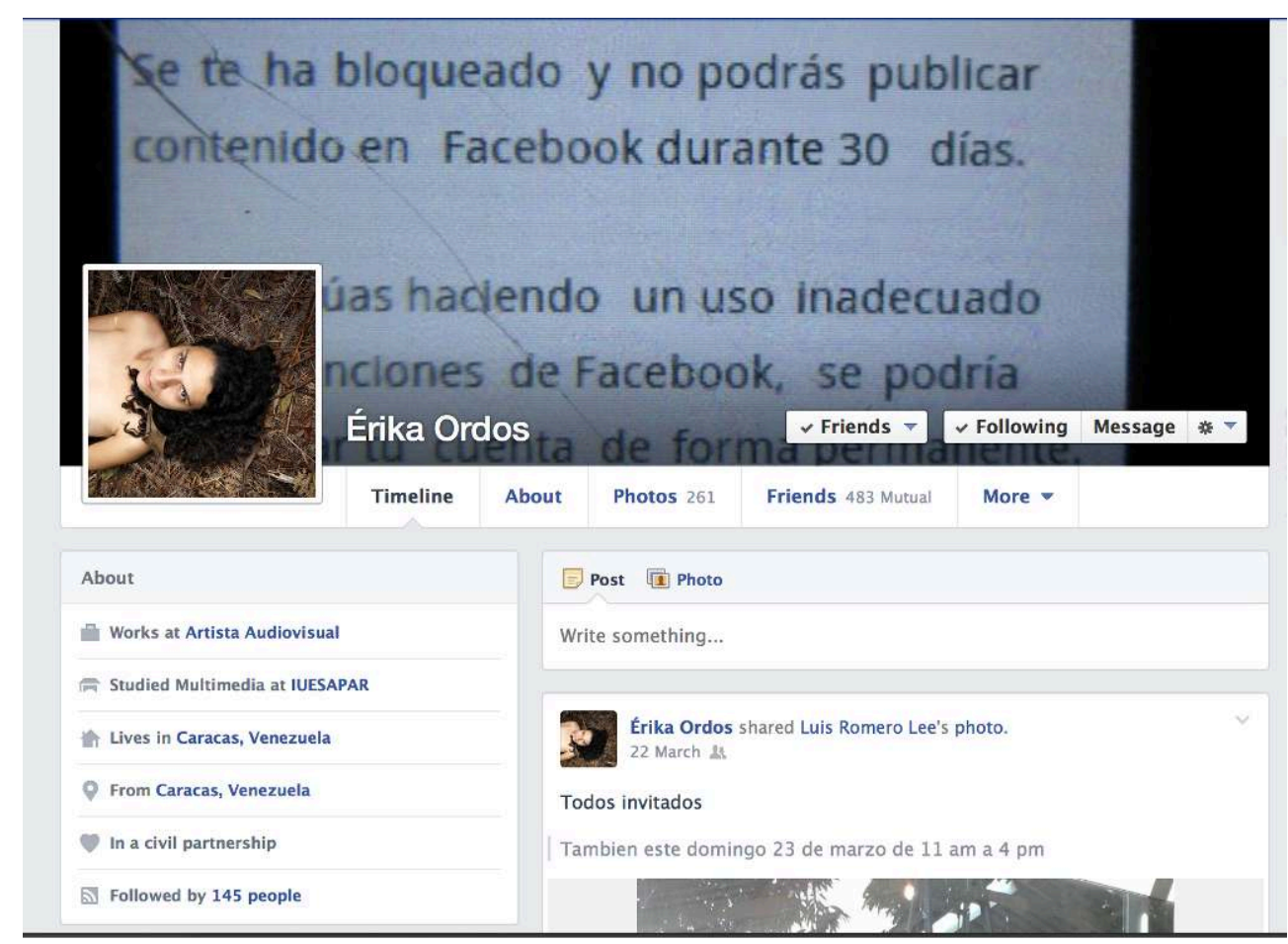

Significantly, Ordosgoitti's choice of cover picture on her Facebook profile makes it evident that she is no stranger to the cycle of censorship, sanction, imposed by the social network's content moderators and her re-publication of the disciplinary messages are part of her practice, as the image above shows. The cover photo depicts the messages she receives to inform her that her naked body has been taken offline. Her insistence on posting and re-posting her nudity is thus a twofold defiant act: it confronts conservative mores regarding nudity, while also countering dominant trends in the visual culture of social media.

Ordosgoitti's images are distinct from conventional modes of self-representation, now gathered under the blanket term "selfies", for various reasons. First, although she orchestrates her self-portraiture through fotoperformance, she does not hold the camera herself. Second, her images do not resemble the playfulness and experimentation that Lasén \& Gómez-Cruz attribute to online self-portraits, nor the desire to depict a positive self-image according to received codes of beauty. Third, while the referents in her photographs stimulate debate, as occurred with the Flickr groups that Gómez-Cruz discusses in his ethnographic work of online communities, the recurrent censorship directs the focus to a critical engagement with the digital interface that bears echoes of the institutional critique of the museum deployed by artists within the museum (LASÉN \& GÓMEZ-CRUZ, 2009).

31 Against such mores, in foregrounding her body's bare organicity, Ordosgoitti opposes the complacency of "like-hunters" and attracts the contempt of "trolls" in equal measures. Indeed, empassioned comments have recently become a central aspect of the exhibition Comida de moscas that Ordosgoitti presented as part of the prize she was awarded by the Fundación Misol in Colombia. The installation Estética de la recepción (2014), for instance, includes print reproductions of the screen shots of comments on her facebook pages (similar to those featured in this article), while the wooden 
structure of the video-installation Comida de moscas (2014) features a ladder whose steps bear digital engravings of insults the artist has received on social media such as "Berro pana tu la verdad es que tienes problemas mentales, qué arte ni que arte" [sic] (Hell dude you've got mental problems, you call this art?) and "haz eso en frente mio y te borro de la faz de la tierra" (do that in front of me and I'll wipe you off the face of the earth). Her nudity and, in particular, the acts carried out in the video Metro Zanahoria that Peña and Peña discuss (PEÑA \& PEÑA, 2013) thus effectively work as agents provocteurs for public comment.

Left: Comida de moscas (2014), video installation. Right: In Defectos corporales, 2012, Ordosgoitti asks people to identify bodily "defects" that need correction. Carora, Venezuela.

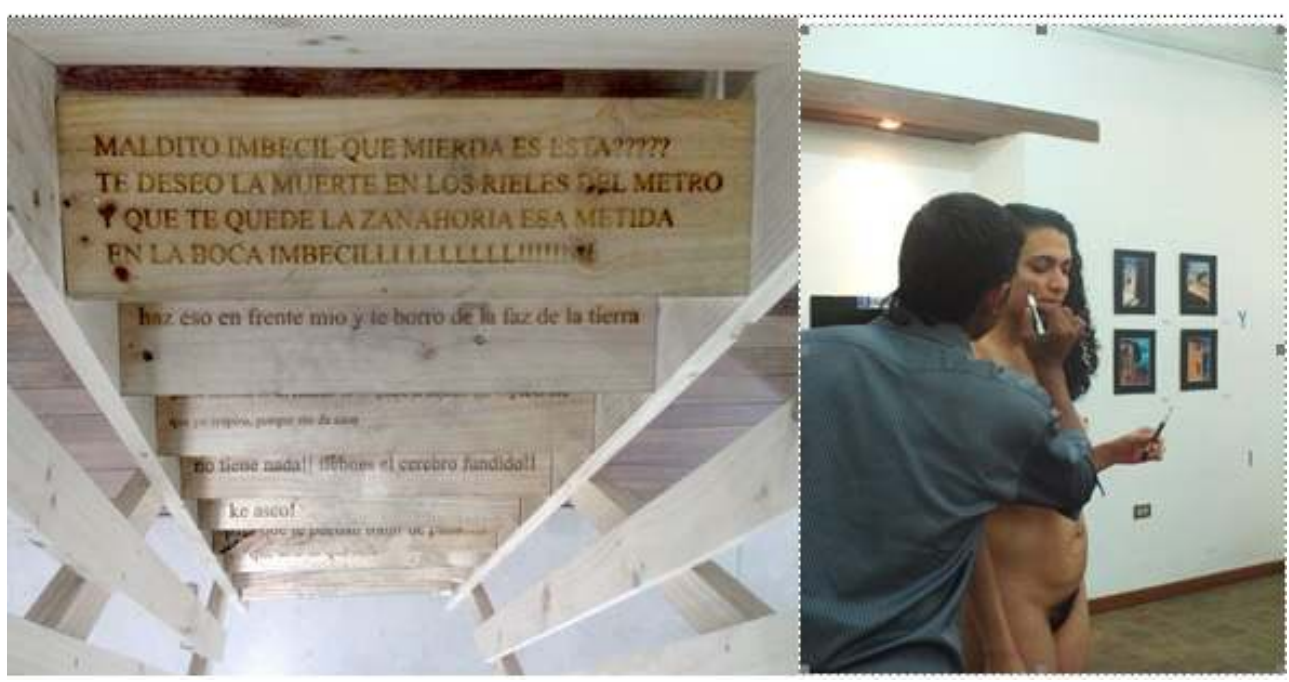

Photo: Érika Ordosgoitti. Photo: unidentified, from artist's Facebook profile.

The tensions between the organic, liminal body that Ordosgoitti focuses on, and the mechanisms that exist to control and curb it evoke a long bio-political history. However, several points are relevant here. First, beyond the contemporary global trends in the west's "selfie" culture, the specific normative codes governing female beauty in Venezuelan society enlighten the polemic and censorship that her work provokes, on the level of specific users who lodge complaints with Facebook. As Ordosgoitti demonstrated quite literally in her performance Defectos corporales (see image above) in a context, like Venezuela, where plastic surgery is commonplace, the female body is a site where conventions are inscribed.

Second, Ordosgoitti's online nudity serves as a constant reminder of the nexus of visuality and power by demonstrating how the global platform of Facebook acts as a panoptical police force that regulates what is and is not acceptable with regards to the human body. Its apparatus mirrors the honorific and repressive functions that Allan Sekula identified at the heart of the interface of body and photograph in nineteenth century photographic practices and archives (SEKULA, 1986). In this sense, Facebook encourages (and accumulates) profile pictures as an honorific self-representation that obtains "likes"; but simultaneously its implements punitive mechanisms to repress photographs that do not meet "Community Standards". Moreover, like the archival impulse that Sekula identifies, Facebook pioneers the accumulation of images to instrumental ends, as was confirmed by the corporation's statement that in 2013 users were uploading 350 million pictures per day to the platform (INTERNET.ORG, 2013: p.6). 
At the same time, however, its content moderators' virtual policing and imposition to disciplinary measures according to criterions of decency reveal the dual facets of this system of representation.

In this setting, the unrelenting presence of Ordosgoitti's contestatory organic corpus stands in critical opposition to the mass of disembodied data of simulated copies of the body that are accumulated online. This is not to say that Ordosgoitti echoes the somewhat clichéd accusation that online life is mere simulacrum; her work suggests more nuanced concerns. By appropriating and re-posting the images of the body the social network deems unfit for public viewing, along with Facebook's chastising comments, ultimatums and suspension of her account, she invites her "friends" to comment on these "censorship loops" and draws attention to the body's circumscription in the honorific and repressive visual regime of social media. Her republication of censorship thus signals the network's invisible disciplinary frames by evincing that, in contrast to the sited archives Sekula discusses, the policing of content in the digital age depends on outsourced global moderators who ultimately administer corporate censorship from various corners of the world.

At bottom, the revelation of these disciplinary measures brings to light the status of the image in the post-Fordist economy epitomised by global corporations such as Facebook, where an "economic considerations enter into human activities previously unrelated to profit, such as social networks and the exchange of contents within them" (CAMPANELLI, 2010: p.95). Ordosgoitti's electronic disturbance inserts her living body into a system that insists on viewing humans as disembodied data. These subversions from within Facebook thus allude to its potential for normalization, which, taken to the extreme, posits users of social media who "speak a single language, and give life to the development of monolithic blocks of beliefs and desires". This "monolingualism", in effect, is none other than a translation of the potential for the hegemony of global corporations to foreshorten the diversity of cultural plurality (CAMPANELLI, 2010: $\mathrm{p}$. 96). ${ }^{5}$

In privileging dialogue, dissent and difference in the para-photographic frame where comments expose plurality, contradiction and disagreement about the spaces the images depict and the naked body that is constantly present, Ordosgoitti diverts the homogenising effect of "pre-established flows and trajectories that expropriates the subjective dimension" to question the homogenising premise of global networks (CAMPANELLI, 2010: p.97). While acting within the Facebook flow, Ordosgoitti's practice reveals the spectre of panoptic control and insists on the use value of images and their capacity to act as catalysts for critical debate beyond the rationalization of photographic exchange value embedded in the corporation's in-built rights to use the images that users post online.

In conclusion, Ordosgoitti posits photographs of her body as a form of "shareware" to spark a collective debate. By publishing polemical images of nudity online, her body creates a site for comment, discussion, and potential censorship, only to bring these same negotiations back to the public forum bearing the marks left by the punitive measures her nudity has provoked. This practice can ultimately be understood as a tactical repurposing of the concept of "circulationism", that Hito Steyerl uses to describe the banality and "suave" vacuity of the Internet. Amid the inherent superficiality that Steyerl detects in the fact that the Internet "is not about the art of making an image, but of postproducing, launching, and accelerating it. It is about the 
public relations of images across social networks, about advertisement and alienation, and about being as suavely vacuous as possible", Ordosgoitti has a contestatory web presence that seeks more complex encounters between users (STEYERL, 2013). In the circulationist context, the photographs of her body act as digital readymades that generate electronic distubance through web traffic, debate and censorship. Hence, circulationism is deployed to critical ends by opening lines of flight that counter the vacuity of "like-hunting", public relations and punitive instruments of normalization that inhere in systems of representation.

In short, Ordosgoitti's electronic disturbance signals a process of enriching crosspollination off and online, in and beyond the conventional "field" of art and across local and global visual regimes. While the discussions catalysed by her photographs recurrently include expressions of disgust and attributions of mental illness, they also stimulate exchanges that question the status of the work of art, of what is art and what is not. While her nudity provokes censorship, her work also makes visible processes of normalization of the female body and the generalized monolinguism that haunts global interfaces of social networking. At bottom, Ordosgoitti's process is an effective electronic disturbance precisely because stimulates debates that are anything but invitations to simply click "like".

\section{BIBLIOGRAPHY}

ANDERSON Benedict, Imagined Communities, London, Verso, 1983.

ARDÉVOL Elisenda \& GÓMEZ CRUZ Edgar, “Cuerpo privado, imagen pública: el autorretrato en la práctica de la fotografía digital”, in Revista de Dialectología y Tradiciones Populares, LXVII:1, 2012, p. 181-208

BAL Mieke, "Visual essentialism and the object of visual culture", in Journal of Visual Culture, 2:5, 2003, p.1-32.

BARTHES Roland, “The Death of the Author" in Image Music Text, trans. by Stephen Heath, Fontana, London, 1977, p.142-8.

BOURDIEU Pierre, The Rules of Art, Standord, Stanford University Press, 1996.

CAMPANELl Vito, Web Aesthetics. How Digital Media Affect Culture and Society, Rotterdam; NAi, 2010.

CHEN Adrian.. "How to Get Boobs on Facebook", in Gawker, 19 February 2011. Retrieved from

http://gawker.com/5765057/how-to-get-a-boob-on-facebook

Critical Art Ensemble., The Electronic Disturbance, New York, Autonomedia, 1994.

Facebook, "Facebook Community Standards", in Facebook, March of 2013. Retrieved from: https:// www.facebook.com/communitystandards

FOSTER Hal, “(Dis)engaged Art”, in Margriet Schavemaker \& Mischa Rakier, Right About Now: Art \& Theory since the 1990s, Amsterdam, Valiz, 2007, p.72-85.

Internet.org., "A Focus on Efficiency”, 2013. Retrieved from: http://internet.org 
Internet World Stats., "South America Internet, Broadband and Facebook Usage" in internetworldstats.com, undated. Retrieved from http://www.internetworldstats.com/south.htmb

La gran ciudad., "La foto: Esta mujer se desnudó sobre la estatua de Simón Bolívar en Barquisimeto" in Lagranciudad.net, 28 April of 2012. Retrieved from http://lagranciudad.net/ home/esta-mujer-se-desnudo-sobre-la-estatua-de-simon-bolivar-en-barquisimeto/

LASÉN Amparo \& GÓMEZ-CRUZ Edgar, “Digital Photography and Picture Sharing: Redefining the Public/Private Divide", in Know Techn Pol, 22, 2009, p.205-215.

LAVERY Jane \& BOWSKILL Sarah, "The Representation of the Female Body in the Multimedia Work of Regina José Galindo", in Bulletin of Latin American Research, 31:1, 2012, p.51-64.

LEE Newton, Facebook Nation. Total Information Awareness, New York, Springer, 2013.

MERGEL Jen, MUNSELl Liz \& fUENMAYOR Jesús, Permission To Be Global, Prácticas Globales Cisneros Fontanals Art Foundation, Miami, 2013.

WJT Mitchell, "Showing seeing: a critique of visual culture", in Journal of Visual Culture, 1:2, 2002, p. 165-181.

ORDOSGOITTI Érika, “Declaración de la independencia”, in Sólo estoy siendo, 2011, 29 July.

Retrieved from http://soloestoysiendo.blogspot.co.uk/2011/07/mi-compromiso-de-vida-es-lalibertad.html

PEÑA ZERPA Claritza Arlenet \& PEÑA ZERPA José Alirio, “Metro Zanahoria: Una lectura desde la pegagogía de la imagen", in Razón y palabra, 85, December of 2013, Retrieved from: http:// www.razonypalabra.org.mx/N/N85/M85/07_PenaPena_M85.pdf.

SCHWARFENBERG Edward, "Maduro crea el viceministerio para las redes sociales", in El País, 22 January of 2014. Retreived from http://internacional.elpais.com/internacional/2014/01/22/ actualidad/1390360885_064780.html

SEKULA Allan, "The Body and the Archive", October, 39, 1986, p.3-64.

SONTAG Susan, On Photography, 2nd edn, London, Penguin Books, 1979.

TAYLOR Claire \& PITMAN Thea, Latin American Identity in Online Cultural Production, London, Routledge, 2013.

TAYLOR Claire, "Resistant Gaming and Resignifying the Border Online: Ricardo Miranda Zúñiga's Vagamundo, A Migrant's Tale”, in Journal of Latin American Cultural Studies: Travesia, 20:3, 2011, p. 303-321.

TAYLOR Diana \& CONSTANTINo Roselyn, Holy Terrors: Latin American Women Perform, Durham \& London, Duke University Press, 2003.

\section{NOTES}

1. To my knowledge, the only published academic article that deal with Ordosgoitti's work is: Claritza Arlenet Peña Zerpa \& José Alirio Peña Zerpa. (2013, December). “Metro Zanahoria: Una lectura desde la pegagogía de la imagen", Razón y palabra, 85. Retrieved from: http:// www.razonypalabra.org.mx/N/N85/M85/07_PenaPena_M85.pdf. In 2013 Dr Elizabeth Marin Hernández from the Departamento de la Historia del Arte at the Universidad de Los Andes in Mérida, Venezuela, wrote a text entitled "Érika Ordosgoitti/Propuesta de nombre" that 
accompanied a homonymous show Ordosgoitti curated of her work. The text, however, remains unpublished.

2. Referring to Latin American artists' use of the female body, Lavery and Bowskill also cite the work of Gabriela León, Astrid Hadad (both from Mexico) and Sandra Monterroso and María Adela Díaz (from Guatemala). See: Jane Lavery and Sarah Bowskill, 'The Representation of the Female Body in the Multimedia Work of Regina José Galindo', Bulletin of Latin American Research, 31: 1 (2012) 51-64.

3. Elsewhere I have explored more recent fotoasaltos and fotoperformances by Ordosgoitti where she poses for the camera in what I argue assert critical reconfigurations of national identity through monumental urban space. See: Lisa Blackmore, "Cuerpo político/cuerpo dócil: críticas y alteraciones del aparato del poder desde la fotografía contemporánea venezolana" (2012). Paper presented at: Cuerpo. Eros y políticas. Encuentro de críticos e investigadores Trasatlántica PHE 2012, Miami, 3-4 December 2012.

4. It is worth noting, however, that art historian José Omaña considers Ordosgoitti's practice anachronistic and modernist inasmuch as her work does not develop institutional critique or critique of the "art field" but instead dissents to gain entry to that same field. Omaña argues that her participation in exhibitions in private galleries and reception of a distinction awarded by the Universidad Central de Venezuela foreshortens her practice's critical scope or transgressive capacity. That said, the author's standpoint is ambivalent, for the purpose of the article he dedicates to her work is itself presented as a call for people to see her exhibition La inestabilidad necesaria at the Galería Universitaria at the Universidad Central de Venezuela. See: José Omaña. (2012, March 8) "Anacronismos de Érika" in Enlapuntadelojo. Retrieved from http:// enlapuntadelojo.blogspot.ch/2012/03/anacronismos-de-erika-ordos.html

5. It is important to note, however, that Campanelli considers that not only do social networks discourage dissent, but that the web itself has been co-opted into the post-Fordist global economy that it serves, stating that: "Today, starting a blog intended to host political content is about as revolutionary as wearing a Che Guevara T-shirt". Nevertheless, other scholars, such as Philip Howard and Muzzamil Hussain in their book Democracy's Fourth Wave? Digital Media and the Arab Spring (Oxford: Oxford University Press, 2013), counter such views by assessing the influence of social media in catalysing collective action in political upheavals.

\section{ABSTRACTS}

The growth of internet penetration in Latin America, as digital culture scholars have revealed (TAYLOR \& PITMAN, 2013), has seen the emergence of tactical media practitioners who push the boundaries of aesthetic form and received discourses. This article examines the use of performance, photography and social media in works by Venezuelan artist Érika Ordosgoitti to assert that her use of Facebook is a deliberate form of "electronic disturbance" (CRITICAL ART ENSEMBLE, 1994) that expands the traditional spatial and temporal horizons of performance. By shorting conventional circuits for the circulation of art, Ordosgoitti's practice engages broader audiences in critical debates about normative controls of photography and bodily representation in social media. Ultimately, the article contends that the depiction of artist's nude body is a critical gesture that replaces the complacent selfie with a contestatory "shareware body". 
La croissance de la pénétration de l'Internet en Amérique latine est témoin de l'émergence de professionnels des "media tactiques" qui repoussent les limites de l'esthétique et les discours conventionnels, dont les chercheurs de la culture numérique ont révélé (TAYLOR \& Pitman, 2013). Notre article traite la performance, la photographie et les médias sociaux dans l'œuvre d'artiste vénézuéliene Érika Ordosgoitti. Je constate que son utilisation de Facebook fait partie d'une stratégie consciente de la "perturbation électronique" (critical disturbance) (CRITICAL ART ENSEMBLE, 1994) qui élargit les horizons spatiaux et temporels traditionnels de la performance. En faisant une court-circuite de la diffusion conventionnelle de l'art, nous engageons un public plus large dans les débats critiques autour des contrôles normatifs de la photographie et sa représentation corporelle dans les médias sociaux. Á la fin, nous maintenons que la représentation d'Ordosgoitti en corps nu représente un geste critique qui remplace la complaisance de la "selfie" avec un "corps de shareware" contestataire.

\section{INDEX}

Mots-clés: internet, selfie, art d'Amérique latine, culture numérique, Érika Ordosgoitti

Keywords: internet, selfie, Latin American art, digital culture, Érika Ordosgoitti

\section{AUTHOR}

\section{LISA BLACKMORE}

Universität Zürich

Post-Doctoral Research Assistant, "Modernity and the Landscape in Latin America” (Swiss National Fund)

lisa.blackmore[at]uzh.ch

My current research examines the interface of sites of aesthetic modernity with mid-twentieth century authoritarian regimes in Colombia, Dominican Republic and Venezuela and the modern legacy today. I have taught at the University of Leeds, Universidad Central de Venezuela and Universidad Simón Bolívar, and published articles in Estudios and the Journal of Latin American Cultural Studies. 